\title{
INTERACTIVE MULTIMEDIA USE TO INCREASE LEARNING INTEREST
}

\section{Anggi Tiarasari, Sukarno, Sarwanto}

Universitas Sebelas Maret

anggitiaraku@gmail.com

\section{Article History}

accepted 09/07/2018

approved 01/08/2018

published 17/09/2018

\section{Keywords}

multimedia interaktif, minat belajar

\begin{abstract}
This paper aims to describe the use of interactive multimedia to enhance interest in learning. Innovative learning media is very important in achieving the learning process. But there are still many teachers who have not literacy will use the latest technology. Therefore, the need for the latest innovations on interactive multimedia. This study uses literature study. Library study is an activity to collect information relevant to the topic or problem that becomes the object of research. Based on literature review shows that not many teachers who use interactive multimedia in learning in the class so that student learning interest is low. Conclusions based on literature review an alternative effort to improve the use of innovative learning media is to create interactive multimedia on learning.
\end{abstract}

Social, Humanities, and Education Studies (SHEs): Conference Series https://jurnal.uns.ac.id/shes 


\section{PENDAHULUAN}

Peningkatan mutu lulusan Lembaga pendidikan harus tetap dilakukan sebagai upaya meningkatkan mutu sumber daya manusia (SDM) baik di tingkat lokal, nasional, dan global. Sumber daya manusia yang handal diharapkan dapat berperan secara aktif dalam memberikan andil bagi peningkatan pembangunan lokal dan nasional, penyediaan tenaga kerja yang handal dan professional, serta dapat menyediakan atau membuka lapangan pekerjaan. Kalau diperhatikan, ada empat aspek globalisasi, yaitu perdagangan, pergerakan modal, pergerakan orang dan penyebaran ilmu pengetahuan dan teknologi. Menurut Indrajit (2006), pergerakan bebas ilmu pengetahuan dan teknologi yang merupakan salah satu aspek penting dalam globalisasi tentu akan menyentuh pula bidang pendidikan. Pendidikan harus mampu berperan dan menyiapkan peserta didik dalam konstelasi masyarakat global dengan tetap melestarikan karakter nasional (Fasli Jalal, 2001). Untuk mengantisipasi tuntutan tersebut, maka Departemen Pendidikan Nasional meluncurkan beberapa kebijakan utama, yaitu pendidikan guru, penerapan teknologi dalam pendidikan, penyempurnaan kurikulum, pengelolaan pendidikan dasar, menengah dan tinggi, pengembangan penelitian dan evaluasi keberhasilan pendidikan nasional.

Dalam penyempurnaan kurikulum dibuktikan dengan lahirnya Kurikulum 2013, yaitu merupakan sebuah kurikulum yang mengutamakan pemahaman, skill, dan pendidikan berkarakter, siswa dituntut untuk paham atas materi, aktif dalam berdiskusi dan presentasi serta memiliki sopan santun disiplin yang tinggi. Kurikulum ini menggantikan Kurikulum Tingkat Satuan Pendidikan yang diterapkan sejak 2006 lalu. Dalam Kurikulum 2013 mata pelajaran wajib diikuti oleh seluruh peserta didik di satu satuan pendidikan pada setiap satuan atau jenjang pendidikan. Penerapan kurikulum 2013, yang menerapkan metode belajar siswa lebih aktif belum sepenuhnya diminati. Hal ini lebih disebabkan masih kurangnya sarana dan prasarana penunjang. Kondisi ini yang membuat reaksi kalangan siswa beragam yang ditandai dengan rendahnya minat belajar pada siswa.

Salah satu masalah utama dalam pembelajaran di kelas adalah bagaimana menghubungkan fakta yang pernah dilihat dan dialami siswa dalam kehidupan seharihari dengan konsep materi ajar. Umumnya pemahaman siswa terpaku pada jabaran konsep yang ada dalam buku, tanpa memahami apa dan bagaimana maknanya. Kenyataan di lapangan masih banyak ditemukan keingintahuan anak yang tinggi itu tidak didukung oleh suatu kondisi pembelajaran yang dapat memberikan kesempatan kepada mereka untuk dapat lebih berkembang. Hampir $90 \%$ guru mengajar hanya menggunakan metode dan media konvensional. Guru merupakan satu-satunya sumber utama pengetahuan. Pembelajaran cenderung berorientasi pada buku (text book oriented) dan tidak terkait dengan kehidupan sehari-hari siswa. Siswa kesulitan untuk memahami konsep yang telah diajarkan. Konsep-konsep tersebut diajarkan menggunakan cara-cara yang abstrak dan metode konvensional dengan cara menghafal materi ajar secara kaku, padahal mereka sangat memerlukan pemahaman konsep-konsep yang berhubungan dengan lingkungan kehidupan sehari-hari. Akibatnya minat dan semangat belajar siswa sulit ditumbuhkan dan pola belajar mereka cenderung menghafal dan mekanistik.

Mencermati situasi dan kondisi pembelajaran di sekolah, seharusnya guru dan pihak sekolah khususnya mampu memahami kebutuhan mendasar yang diperlukan dalam proses belajar. Menurut Mulyasa, (2007) sebuah lembaga pendidikan harus mampu mencermati kebutuhan peserta didik yang bervariasi, keinginan tenaga kependidikan yang berbeda, kondisi lingkungan yang beragam, harapan masyarakat dan kebijakan pemerintah dalam bidang pendidikan. Sebagai implikasinya, terhadap pembelajaran salah satunya adalah perlu diupayakan lingkungan belajar yang kondusif dengan metode dan media yang bervariasi, sehingga setiap peserta didik belajar dengan menyenangkan. 
Lebih jauh lagi dengan penerapan media pembelajaran yang tepat akan memberi beberapa peluang yang terbaik bagi siswa untuk menumbuhkan nilai-nilai positif, yaitu (1) memberikan peluang bagi siswa untuk melibatkan diri secara aktif dalam proses pembelajaran, (2) memberikan kesempatan bagi siswa untuk merekonstruksi pengetahuan secara lebih baik, (3) mendorong siswa untuk mengembangkan sendiri pengalaman belajarnya sesuai strategi yang diminatinya, (4) mendorong siswa agar lebih bertanggung jawab dan berani mengambil resiko, (5) memberikan kesempatan dan kebebasan menyampaikan ide dan pendapat atau mendengaran ide temannya secara leluasa, (Sullivan, 2003).

Salah satu media yang sesuai untuk mengantisipasi hal tersebut perlu didukung media pembelajaran yang sesuai, yaitu Multimedia Interaktif. Penggunaan multimedia interaktif sebagai salah satu media pembelajaran diharapkan dapat membantu efektivitas proses pembelajaran serta penyampaian pesan (isi) pelajaran, selain itu juga akan memberikan penguasaan konsep yang sebenarnya secara realistis dan juga dapat membangkitkan minat dan kreativitas belajar siswa. Hal ini disebabkan karena kemampuan multimedia interaktif yang menggabungkan dua unsur atau lebih media yang terdiri atas teks, grafis, gambar, foto, audio, video, dan animasi secara terintegrasi. Multimedia ini berjalan sekuensial (berurutan). Multimedia inteaktif adalah suatu multimedia yang dilengkapi dengan pengontrol yang dioperasikan oleh pengguna, sehingga pengguna dapat memilih apa yang dikehendaki untuk proses selanjutnya. Contoh multimedia interaktif adalah multimedia pembelajaran interaktif dalam bentuk CD pembelajaran, aplikasi game, tutorial, drill and practie dan lain-lain.

Penggunaan media pembelajaran secara tepat dan bervariasi dapat mengatasi sikap pasif pada anak dalam belajar dan dapat meningkatkan kemampuan mengingat informasi materi ajar dan perkembangan inteligensi ganda. Harapan dari tujuan belajar ini sesuai pendapat Nelson (2001), "Concepts and information learned must be actively used si that the brain transfers learning from short-term to long term memory". Penerapan multimedia dapat meningkatkan kualitas mengingat anak dari ingatan jangka pendek menjadi ingatan jangka panjang. Multimedia pembelajaran merupakan lingkungan belajar berbasis komputer yang memanfaatkan fleksibilitas komputer untuk memecahkan masalah-masalah belajar. Menurut Lee \& Owens (2004), sebagaimana kebanyakan sistem mengajar, komputer dapat digunakan sebagai alat mengajar untuk memberi penguatan belajar, merangsang untuk belajar, dan memotivasi untuk belajar. Banyak manfaat yang diperoleh dari fleksibilitas komputer karena dapat memasukkan video, audio, elemen-elemen grafis, bentuk-bentuk tampilan, dan proses pembelajaran.

Menurut Smaldino (2012), "Jika seorang guru ingin meningkatkan hasil belajar, minat dan aktivitas belajar siswa, maka salah satu perubahan yang dilakukan adalah merubah lingkungan (kondisi) belajar siswa". Salah satu bentuk perubahan lingkungan adalah lingkungan fisik berupa penggunaan teknologi dan media pembelajaran yang tepat. Selain itu media pembelajaran juga dapat memudahkan penafsiran data dan memadatkan informasi. Hal ini memungkinkan tercapainya tujuan pembelajaran, aktivitas belajar, hasil belajar dan minat belajar.

Aspek minat terdiri atas aspek kognitif dan aspek afektif. Aspek kognitif berupa konsep positif terhadap suatu objek dan berpusat pada manfaat dari objek tersebut. Aspek afektif tampak rasa suka atau tidak senang terhadap objek tersebut (Taufani, 2008). Minat terhadap pelajaran tertentu yang dimiliki seseorang bukan bawaan sejak lahir, tetapi dipelajari melalui proses penilaian kognitif dan penilaian afektif seseorang yang dinyatakan dalam sikap. Dengan kata lain, jika proses penilaian kognitif dan afektif seseorang terhadap objek minat adalah positif maka akan menghasilkan sikap positif dan menimbulkan minat. Minat merupakan salah satu factor pokok untuk meraih sukses dalam studi. Salah satu sebab utama dari kegagalan studi para pelajar menunjukkan bahwa penyebabnya adalah kekurangan minat (Gie, 1998). Menurut Gie (1998), arti penting minat belajar dalam kaitannya dengan pelaksanaan studi adalah: 1) 
Minat melahirkan perhatian yang serta merta, 2) Minat memudahnya terciptanya konsentrasi, 3) Minat mencegah gangguan dari luar, 4) Minat memperkuat melekatnya bahan pelajaran dalam ingatan, dan 5) Minat memperkecil kebosanan belajar belajar dalam diri sendiri.

\section{METODE}

Bentuk penelitian ini adalah penelitian kualitatif deskriptif. Teknik pengumpulan data dalam paper ini menggunakan studi kepustakaan. Studi kepustakaan adalah kegiatan untuk menghimpun informasi yang relevan dengan topik atau masalah yang menjadi obyek penelitian. Informasi tersebut dapat diperoleh dari buku-buku, karya ilmiah, tesis, disertasi, ensiklopedia, internet, dan sumber-sumber lain.

\section{Hakikat Multimedia Interaktif \\ Pengertian Multimedia Interaktif}

HASIL DAN PEMBAHASAN

Ariesto Hadi Sutopo (2003) menyatakan bahwa multimedia interaktif (interactive multimedia) atau non linear multimedia adalah multimedia yang dapat menangani interaktif user, dimana user dapat memilih apa yang akan dikerjakan selanjutnya, bertanya dan mendapat jawaban yang akan mempengaruhi komputer untuk mengerjakan fungsi selanjutnya. Artinya, multimedia membutuhkan keterlibatan aktif dari penggunanya. Penggunalah yang menentukan jalannya program sesuai bahasa pemrogramannya. Sementara Daryanto (2010) menyatakan bahwa multimedia interaktif adalah suatu multimedia yang dilengkapi dengan alat pengontrol dan dapat dioperasikan oleh pengguna, sehingga pengguna dapat memilih apa yang dikehendaki untuk proses selanjutnya. Pernyataan ini menunjukkan bahwa salah satu ciri multimedia interaktif adalah memiliki alat pengontrol. Alat pengontrol ini memungkinkan pengguna untuk menentukan proses sesuai keinginannya.

Sedangkan Munir (2012) menyatakan bahwa multimedia interaktif adalah suatu tampilan multimedia yang dirancang agar tampilannya memenuhi fungsi menginformasikan pesan dan memiliki interaktifitas dengan penggunanya. Pengertian ini merujuk pada kemampuan multimedia interaktif untuk berkomunikasi dengan penggunanya. Tampilannya dirancang agar pengguna dapat memperoleh informasi yang interaktif. Multimedia sendiri diartikan oleh Russel (2011) "multimedia is the sequential or simultaneous of a variety of media in a presentation or self-study program. Computers are often involved in multimedia presentations that incorporate text, audio, and still or animated images". Artinya multimedia adalah serangkaian dari beberapa macam media dalam sebuah presentasi atau program belajar mandiri. Komputer sering digunakan dalam presentasi multimedia yang menyatukan teks, audio, dan gambar diam atau bergerak. Pernyataan ini menunjukkan pengertian multimedia sebagai suatu kesatuan antara berbagai media seperti teks, audio, dan gambar.

Berdasarkan pengertian-pengertian di atas, dapat ditarik kesimpulan bahwa multimedia interaktif adalah suatu tampilan multimedia menggunakan komputer yang mengintegrasikan beberapa macam media dimana pengguna dapat belajar secara interaktif karena dilengkapi dengan alat pengontrol yang berfungsi sebagai penghubung dengan program agar pengguna dapat memilih apa yang dikehendaki. Dalam penelitian ini keinteraktifan media didapat dari adanya pilihan menu materi yang dapat dipelajari sesuai keinginan siswa dan adanya umpan balik apabila siswa selesai mengerjakan sesuatu.

\section{Model-model Multimedia Interaktif}

Deni Darmawan (2012) menyatakan bahwa ada empat model multimedia interaktif, yaitu model drills, model tutorial, model simulasi, dan model games.

1. Model Drills 
Model ini pada dasarnya memberikan pengalaman belajar yang lebih konkret dengan penyediaan soal-soal yang bertujuan untuk menguji penampilan siswa melalui kecepatan menyelesaikan soal-soal yang diberikan.

Tahapan materi model drills yaitu sebagai berikut.

a. Program menyajian masalah dalam bentuk soal.

b. Siswa mengerjakan soal-soal latihan.

c. Program merekam penampilan siswa, mengevaluasi, dan memberikan umpan balik.

d. Apabila hasil latihan siswa sudah memenuhi kriteria, maka akan program berlanjut ke materi selanjutnya, namun jika belum akan ada fasilitas remidi yang dapat diberikan secara parsial maupun keseluruhan. (Deni Darmawan, 2012)

2. Model Tutorial

Model ini memberikan pengalaman belajar dengan cara memberikan materi atau informasi terlebih dahulu, kemudian siswa diberikan pertanyaan yang berhubungan dengan materi yang telah disajikan. Penyajian materi dapat dilakukan secara bertahap membentuk siklus.

Tahapan pembelajaran dengan model tutorial yaitu:

a. introduction (pengenalan),

b. presentation of information (penyajian informasi atau materi),

c. questions of respons (pertanyaan dan respon),

d. judging of responses (penilaian respon),

e. providing feedback about responses (pemberian balikan respon),

f. remediation (pengulangan),

g. Sequencing lesson segmen (segmen pengaturan pelajaran). (Deni Darmawan: 2012)

3. Model Simulasi

Model ini bertujuan memberikan memberikan pengalaman belajar yang lebih konkret melalui penciptaan tiruan-tiruan bentuk pengalaman yang mendekati suasana yang sebenarnya. Program simulasi akan mendesain bentuk-bentuk animasi yang detail. Ada empat kategori dalam model simulasi yaitu fisik, situasi, prosedur, dan proses.

Tahapan materi dalam model simulasi yaitu:

a. pengenalan,

b. penyajian informasi (simulasi 1 , simulasi 2 , dan seterusnya),

c. pertanyaan dan respon jawaban,

d. penilaian respon,

e. pemberian feedback (umpan balik) tentang respon,

f. pembetulan,

g. segmen pengaturan pengajaran,

h. penutup. (Rusman, Deni Kurniawan, Cepi Riyana, 2013)

4. Model Games

Model ini mendesain pembelajaran yang menyenangkan melalui simulasisimulasi tertentu yang dibutuhkan agar peserta didik mampu menerapkan semua pengalaman belajarnya dalam menyelesaikan masalah yang dprogramkan. Model games bertujuan untuk menyajikan informasi dalam bentuk fakta, prinsip, proses, struktur, sistem yang dinamis, kemampuan memecahkan masalah, pengambilan keputusan, kemampuan kerja sama, kemampuan sosial, dan kemampuan insidental seperti kompetisi yang harus dialami, bagaimana kerja sama, dan aturan-aturan yang harus ditaati dalam membina disiplin siswa.

Tahapan materi dalam model games yaitu sebagai berikut.

a. Introduction (pendahuluan), terdiri atas judul, tujuan, aturan, petunjuk, pilihan permainan. 
b. Body of Instructional Games (bentuk instruksional permainan), terdiri atas skenario, tingkatan permainan, pelaku permainan, aturan permainan, tantangan dalam mencapai tujuan, rasa ingin tahu, kompetisi positif, hubungan bermakna antara permainan dan pembelajaran, kemampuan melawan tantangan, menang atau kalah, pilihan permainan, alur atau langkah-langkah yang harus dilakukan, pergantian tipe kegiatan, dan interaksi dalam bermain.

c. Closing (penutup) berisi pemberitahuan pemenang, pemberian reward, informasi terutama feedback untuk pemain dalam meningkatkan penampilan individual, penutup. (Rusman, Deni Kurniawan, Cepi Riyana, 2013)

Terdapat berbagai model multimedia interaktif yang dapat dipilih sesuai kebutuhan. Peneliti memilih untuk mengembangkan model tutorial sebagai multimedia interaktif dalam penelitian ini karena model tutorial dapat menyajikan materi yang dibutuhkan dengan tampilan menarik serta dapat memberikan latihan soal sebagai evaluasi dari hasil belajar siswa. Melaui multimedia interaktif model tutorial siswa juga diharapkan dapat belajar secara mandiri dengan bantuan komputer, sehingga siswa dapat mengeksplorasi materi sesuai keinginannya.

\section{Kelebihan dan Kelemahan Multimedia Interaktif}

Yuhdi Munadi (2013) memaparkan ada lima kelebihan multimedia interaktif, yaitu sebagai berikut:

1. Interaktif, sehingga dapat dipakai siswa secara individual, siswa diajak untuk terlibat secara auditif, visual, dan kinetik sehingga dimungkinkan informasinya mudah dimengerti.

2. Memberikan iklim afeksi secara individual artinya dapat mengakomodasi siswa yang lamban dalam menerima pelajaran karena dijalankan secara mandiri, tidak pernah lupa dan bosan serta sangat sabar dalam menjalankan instruksi seperi yang diinginkan.

3. Meningkatkan motivasi belajar karena dapat mengakomodasi kebutuhan siswa.

4. Memberikan umpan balik yang segera terhadap hasil belajar siswa.

5. Kontrol pemanfaatannya sepenuhnya berada pada pengguna karena diprogram untuk pembelajaran mandiri.

Sedangkan keterbatasan multimedia interaktif menurut Smaldino, E. Sharon (2011) antara lain sebagai berikut:

1. Hak cipta program yang menyebabkan program multimedia interaktif tidak seluruhnya bisa diakses secara bebas.

2. Ekspektasi yang tinggi dari guru bahwa pembelajaran dengan komputer dapat menigkatkan prestasi belajar, sementara hal ini tidakdapat terjadi begitu saja.

3. Tingkat kompleksitas program yang tinggi bisa menjadi hambatan bagi pengguna.

4. Kurang tersrukturnya informasi yang diperoleh.

Pernyataan-pernyataan di atas menunjukkan bahwa multimedia interaktif memiliki kelebihan dan keterbatasan. Meskipun demikian, keterbatasan yang diungkapkan di atas penulis atasi dengan mengembangkan multimedia interaktif yang dapat diakses melalui sekolah dan internet, tetap mendampingi selama pembelajaran berlangsung dan mengevaluasi hasil belajar, merancang program dengan sederhana dan mampu digunakan oleh siswa, dan menyajikan materi secara terstruktur dibantu oleh ahli materi dan ahli media.

\section{Hakikat Minat Belajar}

\section{Pengertian Minat Belajar}

Minat belajar adalah berasal dari dua kata yaitu "Minat " dan "Belajar ". Kedua kata ini memiliki arti yang berbeda namun saling mempengaruhi satu dengan yang lainnya. Menurut Ahmadi (2009) "Minat adalah sikap jiwa orang seorang termasuk ketiga fungsi jiwanya (kognisi, konasi, dan emosi), yang tertuju pada sesuatu dan dalam hubungan itu unsur perasaan yang kuat". Menurut Slameto (2003), "minat adalah kecenderungan yang tetap untuk memperhatikan dan mengenang beberapa 
kegiatan". Sedangkan menurut Djaali (2008) "minat adalah rasa lebih suka dan rasa ketertarikan pada suatu hal atau aktivitas, tanpa ada yang menyuruh". Dari beberapa pendapat para ahli diatas dapat disimpulkan bahwa pengertian minat adalah rasa senang, tertarik, perhatian, dan keinginan lebih yang dimiliki seseorang terhadap sesuatu, tanpa adanya dorongan.

Djamarah (2011) belajar adalah "serangkaian kegiatan jiwa raga untuk memperoleh suatu perubahan tingkah laku sebagai hasil dari pengalaman individu dalam interaksi dengan lingkungannya yang menyangkut kognitif, afektif dan psikomotor". Demikian pula menurut Khodijah (2014) belajar adalah sebuah proses yang memungkinkan seseorang memperoleh dan membentuk kompetensi, ketrampilan, dan sikap yang baru melibatkan proses-proses mental internal yang mengakibatkan perubahan perilaku dan sifatnya relative permanen. Dengan demikian dapat ditarik kesimpulan bahwa pengertian belajar adalah perubahan dalam diri seseorang yang berupa, pengetahuan, keterampilan dan tingkah laku akibat dari interaksi dengan lingkungannya.

Minat merupakan rasa ketertarikan, perhatian, keinginan lebih yang dimiliki seseorang terhadap suatu hal, tanpa ada dorongan. Minat tersebut akan menetap dan berkembang pada dirinya untuk memperoleh dukungan dari lingkungannya yang berupa pengalaman. Pengalaman akan diperoleh dengan mengadakan interaksi dengan dunia luar, baik melalui latihan maupun belajar. Dan faktor yang menimbulkan minat belajar dalam hal ini adalah dorongan dari dalam individu. Dorongan motif sosial dan dorongan emosional. Dengan demikian disimpulkan bahwa pengertian minat belajar adalah kecenderungan individu untuk memiliki rasa senang tanpa ada paksaan sehingga dapat menyebabkan perubahan pengetahuan, keterampilan dan tingkah laku.

\section{Ciri-Ciri Minat Belajar}

Dalam minat belajar memiliki beberapa ciri-ciri. Menurut Elizabeth Hurlock (1978) menyebutkan ada tujuh ciri minat belajar sebagai berikut:

1. Minat tumbuh bersamaan dengan perkembangan fisik dan mental

2. Minat tergantung pada kegiatan belajar

3. Perkembangan minat mungkin terbatas

4. Minat tergantung pada kesempatan belajar

5. Minat dipengaruhi oleh budaya

6. Minat berbobot emosional

7. Minat berbobot egoisentris, artinya jika seseorang senang terhadap sesuatu, maka akan timbul hasrat untuk memilikinya. berikut:

Menurut Slameto (2003) siswa yang berminat dalam belajar adalah sebagai

1. Memiliki kecenderungan yang tetap untuk memperhatikan dan mengenang sesuatu yang dipelajari secara terus-menerus.

2. Ada rasa suka dan senang terhadap sesuatu yang diminatinya.

3. Memperoleh sesuatu kebanggaan dan kepuasan pada suatu yang diminati.

4. Lebih menyukai hal yang lebih menjadi minatnya daripada hal yang lainnya

5. Dimanifestasikan melalui partisipasi pada aktivitas dan kegiatan.

Dari pendapat di atas dapat disimpulkan bahwa ciri-ciri minat belajar adalah memiliki kecenderungan yang tetap untuk memperhatikan dan mengenang sesuatu secara terus menerus, memperoleh kebanggaan dan kepuasan terhadap hal yang diminati, berpartisipasi pada pembelajaran, dan minat belajar dipengaruhi oleh budaya. Ketika siswa ada minat dalam belajar maka siswa akan senantiasa aktif berpartisipasi dalam pembelajaran dan akan memberikan prestasi yang baik dalam pencapaian prestasi belajar. 


\section{Faktor-Faktor Yang Mempengaruhi Minat Belajar}

Dalam pengertian sederhana, minat adalah keinginan terhadap sesuatu tanpa ada paksaan. Dalam minat belajar seorang siswa memiliki faktor-faktor yang mempengaruhi minat belajar yang berbeda-beda, menurut Muhibbin Syah (2003) membedakannya menjadi tiga macam, yaitu:

1. Faktor internal

Adalah faktor dari dalam diri siswa yang meliputi dua aspek, yakni:

a. aspek fisiologis

kondisi jasmani dan tegangan otot (tonus) yang menandai tingkat kebugaran tubuh siswa, hal ini dapat mempengaruhi semangat dan intensitas siswa dalam pembelajaran.

b. aspek psikologis

aspek psikologis merupakan aspek dari dalam diri siswa yang terdiri dari, intelegensi, bakat siswa, sikap siswa, minat siswa, motivasi siswa.

2. Faktor Eksternal Siswa

Faktor eksternal terdiri dari dua macam, yaitu faktor lingkungan social dan faktor lingkungan nonsosial

a. Lingkungan Sosial Lingkungan sosial terdiri dari sekolah, keluarga, masyarakat dan teman sekelas

b. Lingkungan Non-sosial

Lingkungan sosial terdiri dari gedung sekolah dan letaknya, faktor materi pelajaran, waktu belajar, keadaan rumah tempat tinggal, alat-alat belajar.

3. Faktor Pendekatan Belajar

Faktor pendekatan belajar yaitu segala cara atau strategi yang digunakan siswa dalam menunjang keefektifan dan efisiensi proses mempelajari materi tertentu.

\section{Indikator Minat Belajar}

Menurut Djamarah (2002) indikator minat belajar yaitu rasa suka/ senang, pernyataan lebih menyukai, adanya rasa ketertarikan adanya kesadaran untuk belajar tanpa di suruh, berpartisipasi dalam aktivitas belajar, memberikan perhatian. Menurut Slameto (2010) beberapa indikator minat belajar yaitu: perasaan senang, ketertarikan, penerimaan, dan keterlibatan siswa. Dari beberapa definisi yang dikemukakan mengenai indikator minat belajar tersebut diatas, dalam penelitian ini menggunakan indikator minat yaitu:

1. Perasaan Senang

Apabila seorang siswa memiliki perasaan senang terhadap pelajaran tertentu maka tidak akan ada rasa terpaksa untuk belajar. Contohnya yaitu senang mengikuti pelajaran, tidak ada perasaan bosan, dan hadir saat pelajaran.

2. Keterlibatan Siswa

Ketertarikan seseorang akan obyek yang mengakibatkan orang tersebut senang dan tertarik untuk melakukan atau mengerjakan kegiatan dari obyek tersebut. Contoh: aktif dalam diskusi, aktif bertanya, dan aktif menjawab pertanyaan dari guru.

3. Ketertarikan

Berhubungan dengan daya dorong siswa terhadap ketertarikan pada sesuatu benda, orang, kegiatan atau bias berupa pengalaman afektif yang dirangsang oleh kegiatan itu sendiri. Contoh: antusias dalam mengikuti pelajaran, tidak menunda tugas dari guru.

4. Perhatian Siswa

Minat dan perhatian merupakan dua hal yang dianggap sama dalam penggunaan sehari-hari, perhatian siswa merupakan konsentrasi siswa terhadap pengamatan dan pengertian, dengan mengesampingkan yang lain. Siswa memiliki minat pada obyek tertentu maka dengan sendirinya akan memperhatikan obyek tersebut. Contoh: mendengarkan penjelasan guru dan mencatat materi. 
Tabel 1. Kisi-kisi Angket Minat Belajar

\begin{tabular}{|c|c|c|c|c|}
\hline Variabel & Definisi Variabel & Indikator & Sub Indikator & $\begin{array}{c}\text { No } \\
\text { Item }\end{array}$ \\
\hline $\begin{array}{l}\text { Minat } \\
\text { Belajar }\end{array}$ & $\begin{array}{l}\text { Minat belajar } \\
\text { adalah suatu rasa } \\
\text { lebih suka dan } \\
\text { rasa ketertarikan } \\
\text { mempelajari halhal } \\
\text { baru atau } \\
\text { aktivitas belajar } \\
\text { tanpa ada paksaan } \\
\text { dan tanpa ada } \\
\text { yang menyuruh } \\
\text { Slameto, } \\
(2003: 180)\end{array}$ & $\begin{array}{l}\text { Rasa tertarik, } \\
\text { senang, } \\
\text { bersemangat } \\
\text { untuk belajar }\end{array}$ & $\begin{array}{l}\text { 1. Tertarik } \\
\text { dengan materi } \\
\text { pelajaran } \\
\text { 2. Selalu } \\
\text { bersemangat } \\
\text { dalam } \\
\text { mengikuti } \\
\text { proses } \\
\text { pembelajaran } \\
\text { 3. Merasa jika } \\
\text { senang jidak } \\
\text { mendapatkan } \\
\text { tugas sekolah } \\
\text { 4. Merasa sedih } \\
\text { jika } \\
\text { mengikuti } \\
\text { pembelajaran } \\
\text { di kelas } \\
\text { 5. Merasa } \\
\text { kecewa jika } \\
\text { guru } \\
\text { bersangkutan } \\
\text { tidak hadir }\end{array}$ & $\begin{array}{c}1,2, \\
3,4, \\
5,6, \\
7,8, \\
9,10, \\
11,12, \\
13,14, \\
15\end{array}$ \\
\hline
\end{tabular}

Tabel 2. Angket Minat Belajar

\begin{tabular}{|c|c|c|c|c|c|c|}
\hline \multirow{2}{*}{ No } & \multirow{2}{*}{ Pertanyaan } & \multicolumn{5}{|c|}{ Skor } \\
\hline & & 5 & 4 & 3 & 2 & 1 \\
\hline 1 & Saya sangat tertarik dengan mata pelajaran ... & & & & & \\
\hline 2 & Saya selalu bersemangat mengikuti proses pembelajaran ... & & & & & \\
\hline 3 & Saya merasa sangat senang mengikuti pelajaran ... & & & & & \\
\hline 4 & Saya selalu bersungguh-sungguh mengikuti pelajaran ... & & & & & \\
\hline 5 & Saya merasa sangat senang jika mendapatkan tugas ... & & & & & \\
\hline 6 & Saya merasa kecewa jika Guru ... tidak hadir & & & & & \\
\hline 7 & Saya tetap hadir di kelas walaupun Guru ... tidak ada & & & & & \\
\hline 8 & Saya selalu mengikuti Test maupun ujian ... & & & & & \\
\hline 9 & Saya sangat senang mengikuti test maupun ujian ... & & & & & \\
\hline 10 & Saya sangat nyaman belajar ... & & & & & \\
\hline 11 & $\begin{array}{l}\text { Saya selalu memahami pelajaran saat pembelajaran sedang } \\
\text { berlangsung }\end{array}$ & & & & & \\
\hline 12 & $\begin{array}{l}\text { Saya selalu bertanya kepada guru ... jika mendapatkan } \\
\text { kesulitan }\end{array}$ & & & & & \\
\hline 13 & $\begin{array}{l}\text { Saya selalu antusias ketika guru ... memberikan pertanyaan di } \\
\text { kelas }\end{array}$ & & & & & \\
\hline 14 & Saya mengerjakan tugas ... yang diberikan guru dengan baik & & & & & \\
\hline 15 & Saya selalu mengerjakan tugas ... tanpa mencontek & & & & & \\
\hline
\end{tabular}




\section{SIMPULAN}

Pembelajaran yang menyenangkan sangat diperlukan siswa untuk meningkatkan minat belajar. Guru dituntut untuk menggunakan/ menciptakan media pembelajaran yang inovatif sesuai dengan kebutuhan siswa. Diharapkan dengan adanya media pembelajaran yang inovatif, siswa mampu mengikuti pembelajaran dengan maksimal. Adanya multimedia interaktif siswa dilatih untuk memanfaatkan IT, dan menuntut siswa untuk aktif dalam pembelajaran di kelas.

\section{DAFTAR PUSTAKA}

Ahmadi, Abu. (2009). Psikologi Sosial. Jakarta: Rineka Cipta

Ariesto Hadi Sutopo. (2003). Multimedia Interaktif dengan Flash. Yogyakarta: PT. Graha Ilmu.

Arthur. Sullivan, Steven M. Sheffrin. (2003). Economics: Principles in action. Upper Saddle River, New Jersey, Pearson Prentice Hall

Daryanto. (2010). Media Pembelajaran, Peranannya Sangat Penting dalam Mencapai Tujuan Pembelajaran. Yogyakarta: Gava Media.

Deni Darmawan. (2012). Inovasi Pendidikan. Bandung: PT Remaja Rosdakarya.

Djaali. (2008). Psikologi Pendidikan. Jakarta: Bumi Aksara.

Djamarah, Syaiful Bahri. (2002). Psikologi Belajar. Jakarta: PT. Rineka Cipta.

Djamarah, Syaiful Bahri. (2011). Psikologi Belajar. Jakarta: PT Rineka Cipta.

Elizabeth B. Hurlock. (1978). Perkembangan Anak. Jakarta: Penerbit Erlangga

Gie, The Liang. (1998). Ensiklopedia Administrasi. Jakarta: Gunung Agung

Indrajit, R.E., R. Djokopranoto. (2008). Manajemen Perguruan Tinggi Moderen. Yogyakarta: CV. Andi Offset.

Jalal, F., Dedi Supriyadi. (2011). Reformasi Pendidikan dalam Konteks Otonomi Daerah. Jakarta: Depdiknas-Bappenas-Adicita Karya Nusa

Khodijah, Nyayu. (2014). Psikologi Pendidikan. Jakarta: Raja Grafindo Persada.

Lee, William.E \& Owens, Diana.L. (2004). Multimedia-Based Instructional Design: Computer-Based Training Program, Web-Based Training, Distance Broadcast Training, Performance-Based solutions Second Edition. San Francisco: Pfeiffer.

Muhibbin Syah. (2003). Psikologi Belajar. Jakarta: PT. Raja Grafindo Persada

Mulyasa, E. (2007). Menjadi Kepala Sekolah yang Profesional. Bandung: PT. Remaja Rosdakarya.

Munir. (2012). Multimedia (Konsep dan Aplikasi dalam Pendidikan). Bandung: Alfabeta.

Nelson, Kristen. (2001). Teaching in the Cyberage: Lingking the Internet and Brain Theory. Arlington Heights, Illionis: SkyLight training and Publishing Inc

Rusman, Deni Kurniawan, Cepi Riyana. (2013). Pembelajaran Berbasis Teknologi Informasi dan Komunikasi: Mengembangkan Profesionalitas Guru. Jakarta: Rajawali Pres.

Slameto. 2003. Belajar dan Faktor-faktor yang Mempengaruhinya. Jakarta: PT Rineka Cipta

Slameto. 2010. Belajar dan faktor-faktor yang Mempengaruhinya. Jakarta: PT. Rineka Cipta

Smaldino, Sharon. E., Lowther, Deboran. L., Russel, James.D. (2011). Teknologi Pembelajaran dan Media untuk Belajar. (Alih Bahasa: Arif Rahman). Jakarta: KENCANA.

Smaldino. Sharon. E. (2012). Intructional Technology and Media for Learning. Penterjemah: Arief Rahman. Jakarta: Kencana.

Taufani. (2008). Minat, Faktor-faktor yang Mempengaruhi. Jakarta: Rineka Cipta

Yuhdi Munadi. (2013). Media Pembelajaran, Sebuah Pendekatan Baru. Jakarta: REFERENSI (GP Press Group). 